\title{
Endocrine complications in patients with thalassaemia major
}

\author{
Zhe Meng*, Liyang Liang, Lina Zhang, Liping Hou, Zulin Liu, Xiangyang Luo, Jianpei Fang, Zhanwen He, \\ Dongfang Li
}

\section{From 7th APPES Biennial Scientific Meeting}

Nusa Dua, Bali. 14-17 November 2012

Thalassemia major is an inherited hemoglobin disorder characterized by chronic anemia and iron overload due to transfusion therapy and gastrointestinal absorption. Iron overload causes severe endocrine complications in patients with multi-transfused thalassaemia major. Endocrine complications includes short stature, acquired hypothyroidism and hypoparathyroidism, hypogonadism, glucose intolerance and diabetes mellitus.

\section{Aim}

The main objective of this study is to determine the prevalence of prominent thalassemia complications.

\section{Methods}

Eighty-seven patients entered the study in our hospital. The patients have a mean age of 10.5 (range, 5-16) years. Physicians collected demographic and anthropometric data and the history of therapies as well as menstrual histories. Patients have been examined to determine their pubertal status. Serum levels of ferritin, glucose, insulin, A1c, cortisol, ACTH,calcium, phosphate, PTH were measured. Thyroid function was assessed by T3, T4 and TSH.

\section{Results}

Short stature was seen in $32.2 \%$ of our patients. Diabetes was present in $10.3 \%$, Primary hypothyroidism and hypoparathyroidism was present in $6.9 \%$ and $1.15 \%$ of the patients. Hypocalcemia was 9.2\%. Cortisol and ACTH were normal. About $10.3 \%$ of patients had more than one endocrine complication with mean serum ferritin of 3125 micrograms/lit.

Department of Pediatrics, Sun Yat-Sen Memorial Hospital, Sun Yat-Sen University, GuangZhou City, China

\section{Conclusion}

High prevalence of endocrine complications among our thalassemics signifies the importance of more detailed studies along with therapeutic.

Published: 3 October 2013

doi:10.1186/1687-9856-2013-S1-P55

Cite this article as: Meng et al:: Endocrine complications in patients with thalassaemia major. International Journal of Pediatric Endocrinology 2013 2013(Suppl 1):P55.
Submit your next manuscript to BioMed Central and take full advantage of:

- Convenient online submission

- Thorough peer review

- No space constraints or color figure charges

- Immediate publication on acceptance

- Inclusion in PubMed, CAS, Scopus and Google Scholar

- Research which is freely available for redistribution
C Biomed Central 